\title{
UNDERGROUND ECONOMY IN INDONESIA
}

\author{
Sri Juli Asdiyanti Samuda ${ }^{7}$
}

\begin{abstract}
This paper estimates the size of underground economic activity in Indonesia. Underground economy covers market production of goods and services, legal and illegal, which are sold or purchased illegally. Using monetary approach, this paper concludes the average size of the underground economy in Indonesia during 2001-2013 was 8.33 percent of GDP. Consequently, the average size of potential tax loss was Rp. $11,172.86$ billion or about one percent of GDP.
\end{abstract}

Keyword: Underground economy, tax evasion

JEL Classification: E26, H26, K42

1 Sri Juli is working at BPS (Badan Pusat Statistik) Kabupaten Kepulauan Sula, Indonesia; srijuli@bps.go.id 


\section{PENDAHULUAN}

Underground economy merupakan bagian yang tidak terpisahkan dari kegiatan ekonomi sebagian besar negara. Underground economy yaitu kegiatan-kegiatan ekonomi baik secara legal maupun illegal yang terlewat dari perhitungan Produk Domestik Bruto (PDB) yang juga dikenal dengan nama lain unofficially economy atau black economy saat ini telah menjadi sebuah isu global (Scheineider\&Enste, 2000). Hal ini dapat dipahami karena semakin meningkatnya kegiatan underground economy mengakibatkan kinerja perekonomian yang selama ini diukur melalui besarnya Produk Domestik Bruto (PDB) menjadi bias atau under estimate. Di sisi lain, semakin berkembangnya kegiatan underground economy juga turut menciptakan kerugian bagi negara melalui besaran potensi pajak yang hilang. Kegiatan underground economy umumnya lepas dari pengawasan otoritas pajak sehingga menghilangkan kewajiban membayar pajak dari para pelaku underground economy yang menyebabkan kerugian negara. Di Indonesia, beberapa contoh kegiatan underground economy yang cukup menyita perhatian melalui pemberitaan pada media massa, baik cetak maupun elektronik diantaranya yaitu kegiatan penyelundupan barang keluar negeri, seperti kayu, bahan bakar minyak (BBM), sampai hewan-hewan langka yang dilindungi, maupun kasus-kasus masuknya barang-barang dari China ke Indonesia tanpa melalui pintu bea cukai. Fenomena ini menyebabkan kerugian negara dalam hal tidak dipungutnya pajak impor dan tidak terbendungnya barang-barang impor yang masuk ke Indonesia.

Pengukuran terhadap underground economy menjadi penting dikarenakan beberapa alasan; pertama, besarnya beban pajak yang harus ditanggung pelaku ekonomi. Meningkatnya aktivitas underground economy dapat dipandang sebagai reaksi dari individu yang merasa terbebani oleh pemerintah dan memilih "exit option" dibandingkan dengan "voice option". Dalam hal ini, meningkatnya kegiatan underground economy menjadi indikator dari tingginya beban pajak yang harus ditanggung pelaku ekonomi. Kedua, perkembangan underground economy dapat menyebabkan ketidakefisienan pengambilan keputusan oleh stakeholder karena pengukuran beberapa indikator ekonomi seperti pengangguran, angkatan kerja, pendapatan dan konsumsi menjadi tidak akurat. Ketiga, efek lain yang perlu diperhatikan yaitu perkembangan dari underground economy dapat menarik pekerja domestik maupun luar negeri untuk beralih dari kegiatan ekonomi yang legal ke illegal dan menciptakan kompetisi antar keduanya.

Dalam upaya untuk mengukur besarnya kegiatan underground economy masih ditemui kesulitan diantaranya karena konsep dari underground economy yang berbeda-beda dan para pelaku underground economy yang umumnya tidak ingin diketahui. Beberapa penelitian sebelumnya menemukan bahwa data yang akurat dari beberapa indikator ekonomi dapat digunakan sebagai proksi dalam mengukur underground economy, salah satunya dengan melihat elastisitas permintaan uang kartal terhadap beban pajak yang diperkenalkan Vito Tanzi (1980) yang juga merupakan pendekatan yang dipakai dalam penelitian ini. Pendekatan ini mengasumsikan bahwa kegiatan underground economy terjadi karena para pelaku underground 
economy ingin menghindari kewajiban membayar pajak yang dibebankan padanya. Penelitian ini bertujuan untuk mengukur aktivitas underground economy yang terjadi di Indonesia selama periode 2001-2013.

Bagian selanjutnya dari paper ini mengulas teori dan studi empiris terkait. Bagian ketiga menyajikan data dan metodologi yang digunakan dalam menghitung besaran underground economy ini, sementara bagian keempat mengulas hasil perhitungan dan analisisnya. Kesimpulan diberikan pada bagian kelima, dan menjadi penutup dari paper ini.

\section{TEORI}

\subsection{Definisi Underground Economy}

Menurut Smith (1994) dalam Faal (2003), Underground economy adalah produksi barang dan jasa baik legal maupun illegal yang terlewat dari penghitungan Produk Domestik Bruto (PDB). Aktifitas illegal yaitu pasar illegal dimana barang dan jasa diproduksi, diperjualbelikan dan dikonsumsi secara illegal. Aktifitas tersebut dikategorikan illegal karena tidak dibenarkan secara hukum (contoh: peredaran obat terlarang atau aktifitas prostitusi). Adapun aktifitas legal yang termasuk underground economy berupa produksi barang dan jasa yang legal namun dengan sengaja diperjualbelikan secara tertutup dengan alasan, yaitu: (i) untuk menghindari pembayaran pajak; (ii) untuk menghindari pembayaran konstribusi perlindungan sosial; (iii) menghindari standar yang telah ditetapkan seperti upah minimum, waktu kerja maksimum, standar keselamatan, dst. (iv) menghindari penyetujuan terhadap prosedur administrasi yang telah ditetapkan.

Adapun klasifikasi aktivitas underground economy menurut Smith (1994) dalam Faal (2003) adalah sebagai berikut: 


\begin{tabular}{|c|c|c|}
\hline \multicolumn{3}{|c|}{$\begin{array}{c}\text { Tabel } 1 . \\
\text { Klasifikasi Aktivitas Underground economy }\end{array}$} \\
\hline \multirow{2}{*}{ Aktivitas } & \multicolumn{2}{|c|}{ Jenis Transaksi } \\
\hline & Transaksi Moneter & Transaksi Non-moneter \\
\hline Illegal & $\begin{array}{l}\text { - } \\
\text { - } \text { Industri dan penjualan obat-obatan terlarang } \\
\text { - Perjudian } \\
\text { - Prostitusi } \\
\text { - Pencucian uang } \\
\text { - Penyelundupan } \\
\text { - Penggelapan }\end{array}$ & 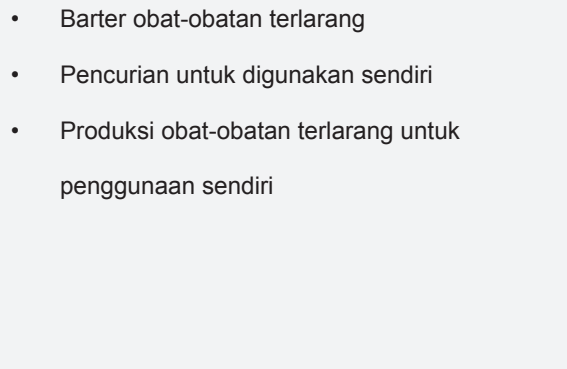 \\
\hline Legal & $\begin{array}{l}\text { - } \\
\text { - Upendapatan yang tidak dilaporkan } \\
\text { dilaporkan dari barang dan jasa yang legal } \\
\text { - } \quad \text { Pembayaran di bawah faktur } \\
\text { - Diskon untuk karyawan } \\
\text { - Tunjangan }\end{array}$ & 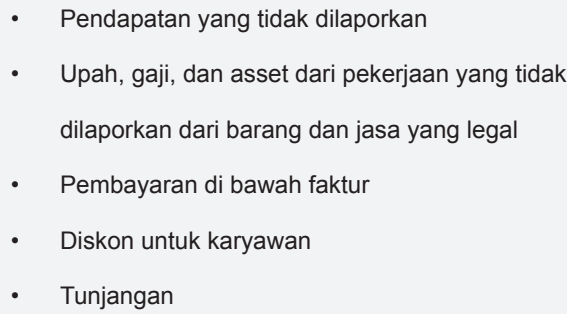 \\
\hline
\end{tabular}

Feige (1990) mengolongkan aktivitas underground economy ke dalam empat golongan, yaitu:

1. The Illegal Economy, yaitu aktivitas ekonomi yang tidak sah yang terkandung dalam pendapatan yang dihasilkan oleh kegiatan ekonomi yang melanggar undang-undang atau bertentangan dengan peraturan hukum. Kegiatan-kegiatan seperti memperjualbelikan barang-barang hasil curian, pembajakan, dan penyelundupan merupakan tindakan kriminal yang melanggar undang-undang. Demikian juga kegiatan perjudian, transaksi-transaksi obat bius dan narkotika merupakan tindakan yang jelas-jelas bertentangan dengan hukum yang ada.

2. The Unreported Economy, yaitu pendapatan yang tidak dilaporkan kepada khususnya otoritas pajak, tentunya dengan maksud untuk menghindari tanggung jawab untuk membayar pajak.

3. The Unrecorded Economy, yaitu pendapatan yang seharusnya tercatat dalam statistik pemerintah namun tidak tercatat. Akibatnya, terjadi perbedaan antara jumlah pendapatan atau pengeluaran yang tercatat dalam sistem akuntansi dengan nilai pendapatan dan pengeluaran yang sesungguhnya. 
4. The Informal Economy, yaitu pendapatan yang diperoleh para pelaku atau agen ekonomi secara informal. Para pelaku ekonomi yang berada dalam sektor ini kemungkinan tidak memiliki izin secara resmi dari pihak yang berwenang, perjanjian kerja, atau kredit keuangan.

\subsection{Metode Penghitungan Underground Economy}

Terdapat beberapa metode pendekatan yang dapat digunakan untuk menghitung estimasi underground economy. Diantara beberapa metode tersebut terdapat tiga pendekatan yang paling sering digunakan yaitu: pendekatan langsung, pendekatan tidak langsung, dan pendekatan dengan pembentukan model.

\section{Pendekatan Langsung}

Pendekatan ini merupakan pendekatan secara mikro dengan melakukan sebuah survei pada sekelompok sampel dengan metode sampel tertentu. Survei didesain untuk mengidentifikasi kegiatan-kegiatan yang termasuk ke dalam aktivitas underground economy. Estimasi underground economy dengan pendekatan langsung melalui survei seperti ini sering dilakukan di beberapa negara besar. Adapun kelebihan dari pendekatan langsung melalui survei adalah informasi yang diperoleh dapat lebih detail melalui pertanyaan-pertanyaan dalam kuesioner. Sementara kelemahannya yaitu keakuratan dari data dari survei sangat dipengaruhi oleh sikap kooperasi dari responden untuk menjawab secara jujur. Seperti telah dijelaskan sebelumnya bahwa para pelaku underground economy cenderung untuk tidak ingin diketahui.

\section{Pendekatan Tidak Langsung}

Pendekatan ini sering juga disebut sebagai pendekatan indikator. Hal ini karena untuk mengestimasi underground economy, berbagai variabel makro ekonomi digunakan sebagai indikator. Indikator yang sering digunakan sebagai proksi untuk mengukur jumlah dan pertumbuhan underground economy antara lain adalah:

\section{Diskrepansi antara PDB Pengeluaran dan PDB Pendapatan}

Pendekatan ini berdasarkan pada diskrepansi statistik antara PDB yang dihitung dengan pendekatan pengeluaran dan PDB yang dihitung melalui pendekatan pendapatan. Secara teori, PDB yang dihitung melalui pendekatan pengeluaran dan pendapatan akan menghasilkan angka yang sama. Perbedaan antara kedua nilai PDB tersebut dapat mengindikasikan terdapat kegiatan underground economy dalam negara tersebut. ${ }^{2}$

2 Smith, J.D (1985): Market motives in the informal economy 


\section{Diskrepansi antara partisipasi kerja di sektor legal dan aktual}

Apabila angka partisipasi kerja tetap, namun angka partisipasi kerja 8ypada sektor legal berkurang maka dapat menjadi indikasi terdapatnya kegiatan underground economy.

\section{Pendekatan Moneter (Permintaan Uang Kartal)}

Metode estimasi dengan pendekatan moneter merupakan salah satu metode yang paling sering digunakan untuk mengukur underground economy. Metode ini dikembangkan oleh Vito Tanzi (1980) yang menggunakannya untuk mengestimasi underground economy di Amerika Serikat. Tanzi mendefinisikan underground economy sebagai pendapatan yang didapat dari aktivitas ekonomi yang tidak dilaporkan dan atau tidak tercatat pada otoritas pajak dengan maksud untuk menghindari pajak. Menurut Tanzi (1980), beban pajak merupakan faktor penyebab terjadinya aktivitas underground economy.

Dalam model yang dibentuk, Tanzi mengestimasi underground economy dengan melihat elastisitas permintaan uang kartal terhadap beban pajak. Hal ini berdasarkan pada asumsi bahwa para pelaku ekonomi yang berada dalam underground economy lebih menyukai menggunakan uang tunai (cash) untuk menghindari pengontrolan oleh pemerintah khususnya otoritas pajak. Model ini mengukur sensitivitas keinginan masyarakat untuk memegang uang kartal terhadap perubahan tarif atau beban pajak. Insentif untuk menghindari pajak dengan menggunakan lebih banyak uang tunai untuk transaksi mampu memengaruhi keinginan masyarakat untuk memegang uang tunai.

\section{Pendekatan dengan Pembentukan Model}

Dalam pendekatan ini, estimasi nilai dari underground economy diperoleh melalui pembentukan model dengan merepresentasikan satu indikator yang dapat mencakup kegiatan underground economy. Model yang terbentuk secara eksplisit terdiri beberapa faktor yang menyebabkan berkembangnya kegiatan underground economy.

Sejumlah penelitian telah dilakukan untuk mengestimasi underground economy di beberapa negara. Asaminew (2010) melakukan estimasi underground economy di Ethiopia dan menemukan bahwa underground economy di Ethiopia mulai berkembang pada tahun 1977-1991 ketika negara tersebut berada pada perang sipil yang berkepanjangan. Pada periode tersebut underground economy di Ethiopia berkisar 41,5 persen dari PDB dan berkurang menjadi 30 persen pada tahun 1993 ketika perang telah berakhir. Haque (2013) dalam penelitiannya mengestimasi underground economy di Bangladesh pada periode 1973-2010. Hasil estimasi dari penelitian tersebut pada tahun 1973 kegiatan underground economy di Bangladesh hanya berkisar 7 persen dari PDB nominal dan meningkat cukup drastis pada tahun 2010 menjadi 62,75 persen dari PDB nominal. 


\section{METODOLOGI}

Dalam paper ini, data yang digunakan adalah data sekunder triwulanan mencakup rentang waktu 2001-2013. Data ini diperoleh dari Badan Pusat Statistik (BPS), Kementerian Keuangan, dan Bank Indonesia (BI).

Penelitian ini melakukan estimasi underground economy dengan menggunakan pendekatan moneter seperti yang diperkenalkan oleh Tanzi (1980). Variabel ekonomi yang digunakan dalam proses perhitungan dalam penelitian ini antara lain, yaitu:

a. Permintaan Uang Kartal (C)

Merupakan jumlah uang kartal baik berupa uang kertas maupun uang logam yang beredar atau berada di tangan masyarakat. Agar mencerminkan nilai sebenarnya maka uang kartal yang digunakan adalah uang kartal riil yaitu uang kartal nominal yang telah disesuaikan dengan tingkat harga umum.

b. Inflasi (I)

Mencerminkan perubahan harga sekelompok barang dan jasa yang dikonsumsi oleh masyarakat atau sebagai proksi daya beli masyarakat. Inflasi secara teori memberikan pengaruh positif terhadap permintaan jumlah uang kartal.

c. Beban Pajak

Sebagai proksi beban pajak digunakan rasio antara penerimaan pajak terhadap PDB nominal. Hal ini sesuai dengan definisi beban pajak menurut Organisation for Economic CoOperation and Development (OECD). Dalam penelitian ini, variabel beban pajak diharapkan berpengaruh positif terhadap permintaan jumlah uang beredar.

d. Suku Bunga Deposito 1 Bulan

Suku bunga deposito 1 bulan diasumsikan sebagai opportunity cost dari memegang uang. Suku bunga deposito 1 bulan secara teori memiliki hubungan negatif terhadap permintaan uang kartal karena semakin tinggi tingkat bunga maka semakin besar keinginan seseorang untuk menabung.

e. Produk Domestik Bruto (PDB)

Data yang digunakan adalah Produk Domestik Bruto Indonesia atas dasar harga berlaku triwulanan dari tahun 2001-2013. PDB diharapkan memiliki pengaruh positif terhadap permintaan uang kuartal.

Adapun persamaan dalam permintaan uang kartal dapat ditulis sebagai berikut:

$$
\ln C_{t}=\beta_{0}+\beta_{1} \operatorname{Inf} t+\beta_{2} \operatorname{Tax}_{t}+\beta_{3} R_{t}+\beta_{4} \ln P D B_{t}+e_{t}
$$


dimana In C merupakan uang kartal yang digunakan untuk transaksi dalam official economy.

Underground economy yang diukur dalam penelitian ini lebih diarahkan ke kegiatan para pelaku ekonomi dalam memproduksi dan memperjualbelikan barang dan jasa yang lepas dari pengawasan otoritas pajak sehingga melepaskan para pelaku tersebut dari kewajiban membayar pajak. Tahapan yang dilakukan dalam penelitian ini untuk memperoleh besarnya underground economy dapat dilihat pada gambar 1 sebagai berikut:

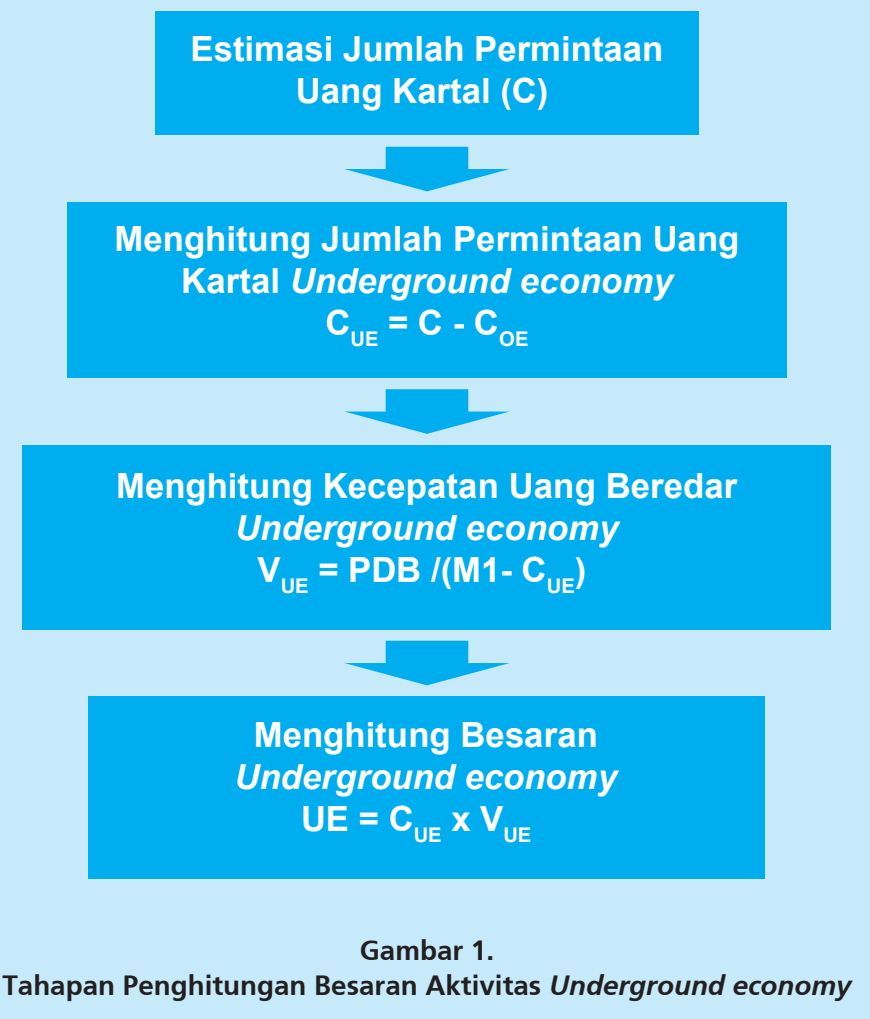

\section{HASIL DAN ANALISIS}

\subsection{Hasil Estimasi dan Validasi Model}

Sebelum mengestimasi model, uji stasioneritas dilakukan terlebih dahulu terhadap serangkaian variabel yang terlibat. Data yang stasioner memiliki means, varians dan autovarians (pada variansi lag) yang sama setiap waktu data itu dibentuk atau dipakai, artinya dengan data yang stasioner model time series yang dibentuk dapat dikatakan lebih stabil. Penggunaan data yang tidak 
stasioner dapat menghasilkan regresi lancung (spurious regression). Sebagaimana kita ketahui, regresi lancung umunya ditandai dengan statistik $R^{2}$ yang tinggi, namun tidak ada hubungan yang berarti diantara variabel dependen dan independennya.

Pengujian dari data yang digunakan dalam penelitian ini menggunakan Augmented Dickey-Fuller test yang hasilnya dapat dilihat pada tabel 4.1. Berdasarkan tabel 4.1 terlihat bahwa pada tingkat level masih terdapat beberapa variabel yang tidak stasioner, sehingga dilakukan differencing pada tahap pertama.

Seperti dijelaskan sebelumnya, model yang diestimasi menggunakan elastisitas permintaan uang kartal terhadap beban pajak. Hal ini disebabkan karena uang kartal merupakan alat transaksi yang paling disukai oleh para pelaku underground economy karena tidak mudah diketahui oleh otoritas pajak. Model ini juga akan mengukur pengaruh perubahan beban pajak terhadap permintaan uang kartal.

Hasil estimasi model yang disajikan dalam Tabel 4.2 menunjukkan bahwa selain variabel inflasi, ariabel lainnya yaitu: beban pajak, suku bunga deposito 1 bulan dan PDB secara signifikan berpengaruh terhadap jumlah permintaan uang kartal.

\begin{tabular}{|c|c|c|c|c|}
\hline \multicolumn{5}{|c|}{$\begin{array}{l}\text { Tabel } 2 . \\
\text { Hasil Regresi Model }\end{array}$} \\
\hline Variabel & Coefficient & Std. Error & $\mathrm{t}$-Statistic & Prob. \\
\hline INF & 0,015139 & 0,016199 & 0,934605 & 0,3550 \\
\hline Tax & 0,015137 & 0,003341 & 4,530057 & 0,0000 \\
\hline $\mathrm{R}$ & $-0,006631$ & 0,003819 & $-1,736099$ & 0,0894 \\
\hline LNPDB & 0,169989 & 0,036330 & 4,679079 & 0,0000 \\
\hline C & 2,751379 & 0,573883 & 4,794318 & 0,0000 \\
\hline R-squared & 0,915849 & & & \\
\hline Adjusted R-squared & 0,906498 & & & \\
\hline F-statistic & 97,95012 & & & \\
\hline Prob(F-statistic) & 0,000000 & & & \\
\hline Durbin-Watson stat & 1,912247 & & & \\
\hline
\end{tabular}

Model di atas masih perlu diuji lebih lanjut yakni uji kointegrasi untuk mengetahui apakah seluruh variabel mempunyai hubungan keseimbangan jangka panjang atau tidak. Secara teknis, uji ini dilakukan dengan melihat ada tidaknya kombinasi linear antara dua atau lebih variabel yang ada dalam model. Dalam penelitian ini, pengujian kointegrasi dilakukan melalui metode Engle Granger dengan pendekatan Augmented Dicky Fuller Test. 
Dari hasil pengujian terlihat bahwa residual dari persamaan yang dibangun ternyata stasioner, sehingga dapat dikatakan terdapat kombinasi linear pada variabel yang terlibat, atau secara singkat terkointegrasi. Hasil ini juga menjelaskan bahwa hasil estimasi dari persamaan yang dibentuk tidak akan membentuk regresi lancung atau spurious regression.

Uji kelayakan model didasarkan pada beberapa hal diantaranya yaitu koefisien determinasi $\left(R^{2}\right)$, nilai t-statistik dan F-statistik. Berdasarkan hasil regresi model diperoleh bahwa nilai koefisien determinasi $\left(R^{2}\right)$ adalah sebesar 0,92 persen. Hal ini berarti bahwa 92 persen jumlah permintaan kartal dapat dijelaskan oleh variabel penjelas yaitu inflasi, beban pajak, suku bunga deposito 1 bulan, dan Produk Domestik Bruto.

Sementara itu, jika dilihat dari nilai F-statistik dengan probabilitas sebesar 0,00 maka dengan tingkat signifikansi 1 persen dapat dikatakan bahwa secara bersama-sama variabel penjelas yang ada dalam model yaitu inflasi, suku bunga deposito 1 bulan, beban pajak dan PDB signifikan berpengaruh terhadap jumlah permintaan uang kartal. Sementara itu, secara parsial dari keempat variabel penjelas yang ada dalam model hanya inflasi yang tidak berpengaruh secara signifikan terhadap jumlah permintaan uang kartal, sedangkan suku bunga deposito 1 bulan, beban pajak dan PDB berpengaruh secara signifikan.

Validasi model juga mencakup uji pelanggaran asumsi yakni multikolinearitas. Dengan melihat nilai VIF, terlihat bahwa tidak ada variabel yang memiliki nilai VIF lebih dari 10 sehingga bisa disimpulkan bahwa seluruh variabel bebas dalam model yang diestimasi tidak melanggar asumsi multikolinearitas.

\begin{tabular}{|c|c|c|}
\hline \multicolumn{3}{|c|}{$\begin{array}{c}\text { Tabel } 3 . \\
\text { NIlai Toleransi dan VIF }\end{array}$} \\
\hline \multirow{2}{*}{ Variabel } & \multicolumn{2}{|c|}{ Collinearity Statistics } \\
\hline & Toleransi & VIF \\
\hline $\mathrm{R}$ & 0,505 & 1,982 \\
\hline PDB & 0,377 & 2,653 \\
\hline $\operatorname{lnf}$ & 0,91 & 1,099 \\
\hline Tax & 0,645 & 1,551 \\
\hline
\end{tabular}

Uji autokorelasi dan heteroskedastisitas juga dilakukan. Model awal memberikan besaran statistik Durbin-Watson sebesar 1,05 yang menunjukkan indikasi masalah autokorelasi pada model. Dengan menambahkan lag, besaran Durbin-Watson ini meningkat menjadi 1,91 sehingga bebas dari masalah autokorelasi. Terkait uji pelanggaran asumsi heteroskedastisitas, hasil pengujian dengan metode White diperoleh nilai F-statistik sebesar 1,38493 dan probabilitas sebesar 0,2050 yang tidak signifikan pada tingkat signifikansi 5 persen sehingga dapat dikatakan bahwa dalam model ini tidak terjadi masalah heteroskedastisitas. 


\subsection{Analisis Hasil Estimasi Model}

\section{Hubungan Inflasi dengan Permintaan Uang Kartal}

Permintaan uang riil adalah permintaan terhadap uang kartal yang dihubungkan dengan perubahan harga barang dan jasa secara umum yang memengaruhi daya beli uang (purchasing power of money). Apabila terjadi inflasi maka dengan jumlah uang nominal yang sama, jumlah barang yang dapat dibeli menjadi lebih sedikit atau dengan kata lain daya beli uang menjadi menurun. Oleh karena itu, secara teori hubungan antara permintaan uang kartal dengan inflasi adalah positif. Hal ini dikarenakan ketika inflasi meningkat maka untuk melaksanakan tingkat transaksi yang sama, jumlah uang yang dibutuhkan secara nominal akan meningkat pula.

Hal ini sesuai dengan hasil penelitian ini dimana diperoleh koefisien inflasi bernilai positif sebesar 0,0151. Meskipun variabel inflasi tidak signifikan secara statistik namun tidak berarti inflasi tidak berpengaruh terhadap permintaan uang kartal. Hal ini bisa saja disebabkan karena pengaruh inflasi yang cukup kecil sehingga tidak signifikan secara statistik dan juga dapat dipahami bahwa ketika terjadi inflasi maka tidak secara seketika masyarakat akan meningkatkan permintaan uang kartal mereka namun dibutuhkan waktu sehingga memberikan pengaruh yang kecil.

\section{Hubungan Beban Pajak dengan Permintaan Uang Kartal}

Variabel beban pajak merupakan variabel penting untuk mengestimasi besaran aktivitas underground economy dan harus berpengaruh signifikan secara statistik terhadap permintaan uang kartal dalam model. Penggunaan uang kartal sebagai alat transaksi lebih memudahkan para pelaku underground economy untuk menghindari kewajiban membayar pajak. Hasil penelitian menunjukkan bahwa variabel beban pajak berpengaruh positif terhadap permintaan uang kartal. Koefisien variabel beban pajak sebesar 0,0151 yang dapat diinterpretasikan bahwa setiap kenaikan dari beban pajak sebesar 1 persen dimana variabel yang lain ceteris paribus maka permintaan uang kartal akan naik sebesar 1,51 persen. Hal ini juga dapat diartikan bahwa beban pajak berpengaruh terhadap peningkatan aktivitas underground economy, dimana semakin tinggi beban pajak semakin besar pula aktivitas underground economy. ${ }^{3}$

\section{Hubungan Suku Bunga Deposito 1 Bulan dengan Permintaan Uang Kartal}

Tingkat suku bunga yang merupakan opportunity cost dari memegang uang, secara teori akan berkorelasi negatif dengan permintaan uang. Hal ini sesuai dengan hasil penelitian dimana koefisien dari suku bunga deposito 1 bulan bernilai negatif sebesar 0,007. Dengan demikian,

3 Peirre Lemieux, (2007) The Underground economy Cause, Extent, Approach, Montreal Economic Institute Research Papers 
setiap suku bunga deposito 1 bulan naik sebesar 1 persen maka jumlah permintaan uang kartal akan turun sebesar 0,7 persen. Secara teori, semakin tinggi tingkat suku bunga deposito maka keinginan masyarakat untuk menyimpan uang di Bank pun akan semakin meningkat karena memperoleh keuntungan yang lebih besar sehingga permintaan uang kuartal pun akan menurun.

\section{Hubungan Produk Domestik Bruto dengan Permintaan Uang Kartal}

Berdasarkan teori yang dikemukakan Keynes, pendapatan mempunyai korelasi positif dengan permintaan uang. Dalam penelitian ini, pendapatan diwakili oleh Produk Domestik Bruto (PDB). Pendekatan seperti ini juga digunakan oleh Ebrima Faal (2003) dalam penelitiannya mengestimasi besarnya aktivitas underground economy di Guyana. PDB dapat digunakan sebagai proksi pendapatan dikarenakan merupakan nilai tambah yang dihasilkan oleh para pelaku ekonomi dalam kegiatan menghasilkan barang dan jasa.

Berdasarkan hasil regresi diperoleh bahwa pendapatan memiliki pengaruh positif terhadap permintaan uang kartal. Koefisien PDB bernilai 0,17 yang berarti setiap kenaikan PDB sebesar 1 persen maka akan meningkatkan jumlah permintaan uang kartal sebesar 17 persen.

\subsection{Pengukuran Besarnya Underground economy}

Hasil estimasi dari persamaan yang terbentuk akan menghasilkan jumlah permintaan uang kartal baik yang digunakan dalam aktivitas official economy maupun dalam underground economy. Hasil estimasi jumlah permintaan uang kartal dengan beban pajak kemudian dikurangi dengan estimasi jumlah permintaan uang kartal tanpa beban pajak untuk memperoleh estimasi jumlah permintaan uang kartal underground economy. Hasil tersebut kemudian dikalikan dengan velocity of money atau kecepatan uang beredar untuk memperoleh besaran underground economy di Indonesia periode 2001-2013 yang disajikan pada tabel 4.5 sebagai berikut: 


\begin{tabular}{|c|c|c|c|c|c|c|c|}
\hline \multicolumn{8}{|c|}{$\begin{array}{l}\text { Tabel } 4 . \\
\text { Estimasi Underground economy di Indonesia, 2001-2013 }\end{array}$} \\
\hline \multirow{2}{*}{ Tahun } & \multirow{2}{*}{ TW } & \multicolumn{2}{|c|}{$\begin{array}{l}\text { Underground economy } \\
\text { (dalam Miliar Rupiah) }\end{array}$} & \multirow{2}{*}{ Tahun } & \multirow{2}{*}{ TW } & \multicolumn{2}{|c|}{$\begin{array}{l}\text { Underground economy } \\
\text { (dalam Miliar Rupiah) }\end{array}$} \\
\hline & & Nominal & Riil (2000) & & & Nominal & Riil (2000) \\
\hline \multirow[t]{4}{*}{2001} & I & 31899,25 & 293,80 & 2008 & I & 104035,46 & 473,51 \\
\hline & II & 29573,92 & 256,26 & & II & 101441,25 & 431,50 \\
\hline & III & 56849,40 & 489,50 & & III & 129354,40 & 524,86 \\
\hline & IV & 40314,81 & 229,73 & & IV & 102143,43 & 411,09 \\
\hline \multirow[t]{4}{*}{2002} & 1 & 33758,58 & 284,80 & 2009 & 1 & 81833,64 & 328,55 \\
\hline & II & 36216,79 & 301,96 & & II & 93224,54 & 364,88 \\
\hline & III & 45594,91 & 374,62 & & III & 118759,42 & 457,41 \\
\hline & IV & 43631,31 & 234,75 & & IV & 34622,35 & 130,84 \\
\hline \multirow[t]{4}{*}{2003} & 1 & 28158,74 & 219,45 & 2010 & 1 & 157109,82 & 583,93 \\
\hline & II & 37544,56 & 297,49 & & II & 80328,31 & 290,56 \\
\hline & III & 57594,81 & 301,76 & & III & 119214,58 & 424,07 \\
\hline & IV & 36615,73 & 283,88 & & IV & 81957,28 & 285,51 \\
\hline \multirow[t]{4}{*}{2004} & 1 & 38516,53 & 192,65 & 2011 & 1 & 134793,25 & 459,06 \\
\hline & II & 49338,56 & 240,06 & & II & 138138,11 & 464,03 \\
\hline & III & 75939,52 & 360,45 & & III & 151378,10 & 496,61 \\
\hline & IV & 70395,54 & 327,34 & & IV & 124896,16 & 406,18 \\
\hline \multirow[t]{4}{*}{2005} & 1 & 44235,53 & 298,44 & 2012 & 1 & 137148,55 & 440,20 \\
\hline & II & 51890,20 & 337,53 & & II & 196591,67 & 625,09 \\
\hline & III & 69986,94 & 440,34 & & III & 212969,48 & 676,01 \\
\hline & IV & 63599,30 & 368,51 & & IV & 106301,74 & 336,33 \\
\hline \multirow[t]{4}{*}{2006} & 1 & 51828,99 & 296,96 & 2013 & 1 & 188571,63 & 590,78 \\
\hline & II & 61261,79 & 344,95 & & II & 140849,84 & 438,49 \\
\hline & III & 91011,78 & 496,62 & & III & 327739,00 & 986,12 \\
\hline & IV & 76500,37 & 272,17 & & IV & 286806,74 & 847,73 \\
\hline \multirow[t]{4}{*}{2007} & 1 & 54863,54 & 283,58 & & & & \\
\hline & ॥ & 81395,83 & 412,46 & & & & \\
\hline & III & 114195,66 & 561,33 & & & & \\
\hline & IV & 72423,59 & 345,07 & & & & \\
\hline \multicolumn{6}{|l|}{ Rata-rata } & 94141,25 & 396,53 \\
\hline
\end{tabular}


Adapun perkembangan dari underground economy di Indonesia selama periode 20012013 disajikan pada Grafik 1. Dari gambar tersebut terlihat bahwa aktivitas underground economy memiliki trend meningkat hampir setiap tahunnya hanya pada tahun 2009 menurun cukup drastis. Peningkatan aktivitas underground economy paling tinggi terjadi pada triwulan III tahun 2013.

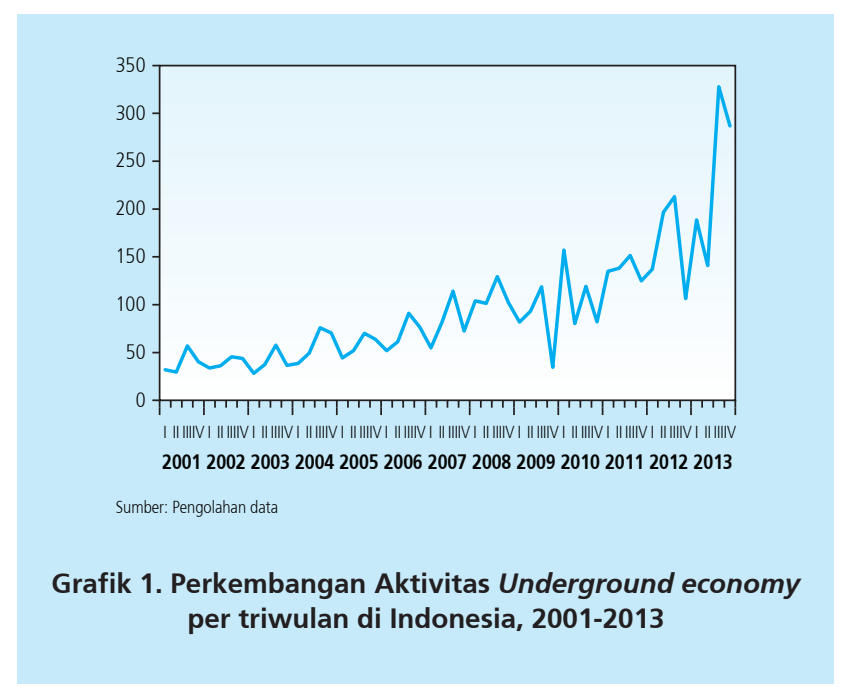

Berdasarkan hasil estimasi underground economy di Indonesia maka akan dapat diperkirakan pula nilai potensi pajak yang hilang karena aktivitas underground economy. Nilai potensi pajak ini diperoleh dengan mengalikan besaran underground economy dengan tarif pajak rata-rata. Perkiraan tarif pajak rata-rata ini diperoleh dari total penerimaan pajak dibagi dengan tax base, dalam hal ini nilai PDB. Berdasarkan hasil penghitungan yang dilakukan diperoleh nilai potensi pajak seperti yang disajikan pada tabel 4.6. Selama periode 2001-2013 rata-rata nilai potensi pajak di Indonesia yang hilang akibat aktivitas underground economy yaitu sebesar 11172,864 miliar setiap triwulannya. Pada tabel 4.6 juga disajikan rasio dari nilai potensi pajak underground economy terhadap PDB nominal. Rasio potensi pajak yang hilang terhadap PDB nominal tertinggi terjadi pada triwulan IV tahun 2013 yaitu sekitar 2,33 atau 55233,76 miliar per triwulan. 


\section{Tabel 5.}

Potensi Pajak Underground economy di Indonesia, 2001-2013

\begin{tabular}{|c|c|c|c|c|c|c|c|}
\hline Tahun & Triwulan & $\begin{array}{l}\text { Potensi Pajak } \\
\text { Nominal (Miliar) }\end{array}$ & $\begin{array}{c}\text { Rasio } \\
\text { terhadap } \\
\text { PDB }\end{array}$ & Tahun & Triwulan & $\begin{array}{l}\text { Potensi Pajak } \\
\text { Nominal (Miliar) }\end{array}$ & $\begin{array}{c}\text { Rasio } \\
\text { terhadap } \\
\text { PDB }\end{array}$ \\
\hline \multirow[t]{4}{*}{2001} & I & 4309,59 & 1,11 & 2008 & I & 11672,78 & 1,05 \\
\hline & II & 3318,19 & 0,80 & & II & 12842,46 & 1,05 \\
\hline & III & 6566,11 & 1,54 & & III & 16803,14 & 1,27 \\
\hline & IV & 7220,38 & 1,73 & & IV & 14269,44 & 1,11 \\
\hline \multirow[t]{4}{*}{2002} & I & 3693,19 & 0,85 & 2009 & I & 8363,40 & 0,64 \\
\hline & II & 3835,36 & 0,85 & & II & 10534,37 & 0,76 \\
\hline & III & 4814,82 & 1,02 & & III & 11769,06 & 0,81 \\
\hline & IV & 6104,02 & 1,32 & & IV & 4878,29 & 0,34 \\
\hline \multirow[t]{4}{*}{2003} & 1 & 3238,25 & 0,65 & 2010 & I & 6259,95 & 0,42 \\
\hline & II & 3900,88 & 0,78 & & II & 14032,77 & 0,88 \\
\hline & III & 5989,86 & 1,16 & & III & 11891,72 & 0,71 \\
\hline & IV & 5770,64 & 1,15 & & IV & 10679,04 & 0,64 \\
\hline \multirow[t]{4}{*}{2004} & 1 & 4317,70 & 0,80 & 2011 & 1 & 10777,22 & 0,62 \\
\hline & II & 5136,14 & 0,91 & & II & 18777,20 & 1,03 \\
\hline & III & 8315,38 & 1,40 & & III & 19081,11 & 0,99 \\
\hline & IV & 11368,88 & 1,90 & & IV & 15830,77 & 0,83 \\
\hline \multirow[t]{4}{*}{2005} & I & 5193,25 & 0,82 & 2012 & 1 & 11473,43 & 0,58 \\
\hline & II & 5879,16 & 0,88 & & II & 21365,66 & 1,04 \\
\hline & III & 8258,46 & 1,16 & & III & 29811,47 & 1,41 \\
\hline & IV & 9438,14 & 1,24 & & IV & 14999,95 & 0,72 \\
\hline \multirow[t]{4}{*}{2006} & 1 & 5867,04 & 0,75 & 2013 & 1 & 13898,73 & 0,65 \\
\hline & II & 7124,75 & 0,88 & & II & 16129,42 & 0,73 \\
\hline & III & 9983,99 & 1,15 & & III & 28430,04 & 1,20 \\
\hline & IV & 11429,16 & 1,31 & & IV & 55233,76 & 2,33 \\
\hline \multirow[t]{4}{*}{2007} & I & 5629,00 & 0,61 & & & & \\
\hline & II & 9303,54 & 0,97 & & & & \\
\hline & III & 13829,09 & 1,34 & & & & \\
\hline & IV & 11348,78 & 1,10 & & & & \\
\hline \multicolumn{6}{|l|}{ Rata-rata } & 11172,864 & 0,9992 \\
\hline
\end{tabular}


Pertumbuhan dari aktivitas underground economy dari tahun ke tahun selama periode 2001-2013 juga dapat dihitung dengan melihat perkembangan dari besarnya underground economy riil. Dengan mengabaikan perubahan tingkat harga dari waktu ke waktu maka perkembangan dari underground economy setiap tahunnya selama periode 2001-2013 disajikan dalam Grafik 2.

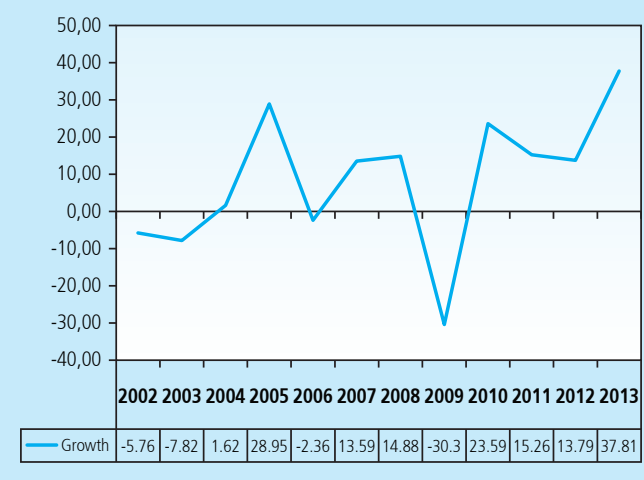

Grafik 2. Pertumbuhan Underground economy di Indonesia, 2001-2013

Dari Grafik 2 terlihat bahwa pertumbuhan aktivitas underground economy di Indonesia cukup fluktuatif setiap tahunnya selama periode 2001-2013. Peningkatan aktivitas underground economy tertinggi terjadi pada tahun 2013 yaitu sebesar 37,81 persen. Sementara itu, pada tahun 2009 kegiatan underground economy menurun drastis sebesar 30,3 persen.

\section{KESIMPULAN}

Paper ini merupakan penelitian empiris yang menghitung dan menganalisis besaran underground economy di Indonesia. Beberapa kesimpulan yang dapat diturunkan pertama adalah bahwa pendekatan moneter dapat digunakan untuk mengestimasi besarnya underground economy di Indonesia, yang ditunjukkan melalui variabel beban pajak yang signifikan berpengaruh terhadap jumlah permintaan uang kartal. Kesimpulan kedua, dengan menggunakan pendekatan moneter, paper ini menyimpulkan bahwa selama periode 2001-2013, rata-rata besarnya underground economy di Indonesia adalah sebesar Rp 94.141,25 miliar atau sekitar 8,33 persen dari Produk Domestik Bruto (PDB) Indonesia untuk setiap triwulannya. Sebagai konsekuensi logis, paper ini menyuguhkan kesimpulan ketiga, yakni bahwa potensi pajak yang hilang akibat aktivitas underground economy di Indonesia periode 2001-2013 rata-rata sebesar Rp. 11.172,86 miliar atau sekitar 1,00 persen dari rata-rata Produk Domestik Bruto (PDB) Indonesia per triwulan. 
Tiga kesimpulan di atas memiliki implikasi penting terutama dalam hal penggunaan uang tunai dalam bertransaksi yang membuka peluang bagi aktivitas underground economy. Kedepannya penggunaan uang elektronik kemungkinan dapat menjadi solusi untuk mereduksi besaran aktivitas underground economy. 


\section{DAFTAR PUSTAKA}

Asaminew, Emerta. (2010). The Underground economy and Tax Evasion in Ethiopia: Implications for Tax, October, typewritten.

Faal, Ebrima. (2003). Currency Demand, the Underground economy, and Tax Evasion: the Case of Guyana. International Monetary Fund Working Paper.

Feige, Edgard. (1990). Defining and Estimating Underground and Informal Economies: The New Institutional Economic Approach, World Development, 18, no. 7, pp. 989 - 1002.

Gujarati, Damodar. (1993). Ekonometrika Dasar. Jakarta: Erlangga.

Haque, Sheikh Touhidul. (2013). Underground economy of Bangladesh: An Econometric Analysis. Research Study Series No - FDRS 01/2013.

Lemmiuex, Pierre. (2007). The Undeground Economy Causes, Extent, Approach. Montreal Economic Institute Research Papers.

Schneider, Friedrich dan Enste, D. H. (2000). Shadow Economies: Size, Causes, and Consequences. Journal of Economic Literarute, Vol.38, pp. 77-114.

Smith, J. D. (1985). Market motive in the Informal Economy. The Economics of the Shadow Economy.

Tanzi, Vito. (1980). The Underground Economy in the United States: Annual Estimates, 193080. IMF Staff Papers, Vol. 30 (June), pp. 283-305. 